\title{
Presupozycje JAKo formy MANiPUlaCji JęzYKowej
}

\author{
Agnieszka Witek \\ Uniwersytet Papieski Jana Pawła II w Krakowie \\ Kanonicza 25, 31-002 Kraków \\ Email: agnieszka_witek@poczta.fm \\ ORCID: https://orcid.org/0000-0002-0624-9945
}

\begin{abstract}
Abstrakt
Cel: Celem pracy jest przybliżenie pojęcia presupozycji i przedstawienie jej użycia w kontekście manipulacji językowej w mediach na wybranych przykładach. Artykuł przedstawia różnorodność presupozycji jako formy językowej. Praca ukazuje również mnogość rodzajów tej figury pragmatycznej.

Metoda: Analiza jakościowa posłużyła do przybliżenia techniki posługiwania się presupozycją jako formą manipulacji. Szerokiemu badaniu jakościowemu poddane zostały dwa przykłady, które zaistniały w dyskursie medialnym. Ważnym aspektem analizy jest również ukazanie kontekstu wypowiedzi, dzięki czemu odbiorca ma świadomość, w jaki sposób i w jakich okolicznościach przekaz zaistniał.

Wyniki: Analiza wykazała, w jaki sposób ludzie mediów i polityki stosują presupozycje, by w podświadomości odbiorcy zakomunikować swój osąd, bez ukazania go w sposób bezpośredni. Różnorodność tej figury pragmatycznej przyczynia się do różnorodności jej zastosowań w dyskursie medialnym.

Wnioski: Umiejętnie zastosowana presupozycja stanowi doskonałą praktykę manipulacyjną. Zgłębianie tego tematu przyczyni się do poszerzenia świadomości odbiorców wypowiedzi medialnych, którzy nie posiadając odpowiedniej wiedzy, stają się dobrym materiałem do stosowania praktyk manipulacyjnych. Presupozycja ze względu na swoją specyfikę niełatwa jest do odszyfrowania, co czyni ją interesującym przedmiotem badań w kontekście manipulacji.

Słowa kluczowe: presupozycja, manipulacja językowa, manipulacja w mediach, język mediów, pragmatyka językowa

\section{Presupposition as a form of language manipulation}

\section{Abstract}

Aim: The aim of this thesis is to introduce the concept of presupposition and present its use in the context of language manipulation in the media through selected examples. The article presents the variety of presuppositions as a linguistic form. The work also shows the multitude of types of this pragmatic figure.
\end{abstract}


Method: Qualitative analysis was used to approximate the technique of using presupposition as a form of manipulation. Two examples which appeared in the media discourse were subjected to extensive qualitative research. An important aspect of the analysis is also to show the context of the statement, so that the recipient is aware of how and under what circumstances the message existed.

Results: The analysis showed how people of the media and politics use presuppositions to communicate their judgment to the subconscious mind without showing it directly. The diversity of this pragmatic figure contributes to the diversity of its applications in media discourse.

Conclusions: Skilfully used presupposition is an excellent manipulative practice. Exploring this topic will contribute to expanding the awareness of the recipients of media statements, who, without proper knowledge, become good material for the use of manipulative practices. Presupposition, due to its specificity, is not easy to decipher, which makes it an interesting subject of research in the context of manipulation.

Key words: presupposition, loaded language, media manipulation, media language, lingual pragmatics

\section{WSTĘP}

Istnieje wiele rodzajów technik manipulacyjnych, które stosowane są po to, aby wpłynąć na postrzeganie rzeczywistości przez odbiorców. Jedną z ciekawszych są manipulacje językowe z użyciem presupozycji. Obserwacja rzeczywistości politycznej i medialnej przez pryzmat tychże prowadzi do ciekawych wniosków.

Pierwsza część artykułu stanowi próbę zdefiniowania pojęć „presupozycji” oraz „manipulacji językowej”, jak również przybliżenia ich etymologii. W drugiej części zaprezentowane zostały przykłady użycia w praktyce presupozycji jako technik manipulacji językowych.

Presupozycja to obok implikatury konwersacyjnej druga ważna idea pragmatyczna. Zainteresowanie tą formą można zaobserwować już w dyskusjach filozoficznych, które tyczyły się wyrażeń referencyjnych i odniesień (Levinson, 2010). Dylematy związane z tego rodzaju kwestiami mają swoje źródło w teorii logicznej. Filozof Gottlob Frege, twórca nowoczesnej logiki, wniósł pewien wkład, który potem stał się istotny w rozmyślaniach nad pojęciem presupozycji. W późniejszych latach z Frege'iem polemizował Rusesell (1905), którego stanowisko nie spotkało się ze znaczącą negacja, aż do czasu kiedy Strawson (1950) przedstawił nieco inne podejście.

Mianowicie zwrócił on uwagę, że jeśli zdanie jest sensowne i ma określone znaczenie, musi być ono prawdziwe lub fałszywe. Określił on warunek wstępny, który musi zaistnieć, aby móc rozważać, czy zadnie jest prawdziwe, czy fałszywe i nazwał go presupozycją. Presupozycja stanowiła również przedmiot zainteresowania Edmunda Burke'a. Można określić go mianem prekursora w tej dziedzinie, ponieważ ten angielski myśliciel z końca XVIII wieku zajął się wprowadzaniem kategorii przed-rozumienia. Są to formy, które prowadzą do tego, iż odbiorca otrzymuje komunikat z niejawnym założeniem skonstruowanym przez nadawcę komunikatu. Wraz z wdrażaniem kategorii przed-rozumienia zaczęto zajmować się presupozycjami (Kolarzowski, 2006). 


\section{PrZYBliżenie POJĘCIA PRESUPOZYCJI}

Presupozycja jest logiczną konsekwencją wypowiedzianych twierdzeń, pełni w języku funkcję perswazyjną. Wnioskowania pragmatyczne zwane presupozycjami są zarówno logiczne, jak również semantyczne, ponieważ włączony zostaje zakres znaczenia wyrazów. Dzięki presupozycji możemy dotrzeć do głębszej pojemności semantycznej wykorzystując zakres logiczny wypowiedzi. Presupozycja jest pewną strukturą lingwistyczna, która niesie dodatkowe informacje, które na poziomie pozaświadomego odbioru, stają się pomocniczym założeniem. Presupozycja nie jest więc wnioskiem, a założeniem dodatkowym (Levinson, 2010).

\section{PREsuPOZYCJE W PRAKTYCE}

Osoby, które na co dzień zajmują się różnego rodzaju technikami perswazyjnymi zauważaja, że najlepiej użyć trzech lub czterech presupozycji, z tego względu, że jedną lub dwie umysł odbiorcy może wychwycić i je rozszyfrować (Kolarzowski, 2006). Należy jednak uważać na zastosowanie zbyt wielu presupozycji w jednym komunikacie, ponieważ może spowodować to, że komunikat stanie się nienaturalny, przez co budzący większą czujność u odbiorcy. Warto zwrócić uwagę na fakt, że odbiorca nie musi zareagować od razu na stosowane presupozycje. Dopiero po pewnym czasie można zauważyć wysiłek włożony w stosowanie presupozycji.

\section{Presurozycje w badaniach Nad MaNipulacja pamięcią}

Słynna badaczka nad pamięcią Elizabeth Lotftus dowiodła, że dzięki zastosowaniu presupozycji można manipulować pamięcią (Maciuszek, Garlicka, 2017). Lothfus przeprowadziła eksperyment, który wykazał, w jaki sposób presupozycje wpływają na zapamiętywanie faktów przez świadków sądowych. Badaczka zadawała pytanie osobom uczestniczącym w wypadku samochodowym: „Ile osób siedziało w samochodzie, który jechał z niedozwoloną prędkością". Pytanie zawiera sugestię (presupozycję) dotyczącą prędkości samochodu. Loftus udowodniła, że informacja o nadmiernej szybkości zostanie dodana do pamięci pierwotnej, a następnie przywoływana w relacjach świadków.

Również Józef Maciuszek (2013) w swoich badaniach udowodnił bardzo mocną tendencję do przyswajania informacji presupuowanych, jako prawdziwych.

Presupozycje wpływają na machinalną akceptację informacji, które przekazywane są odbiorcy. Informacje presupuowane przyjmowane są bez większego zastanowienia się, w sposób automatyczny i bezwiedny. Ich przyswojenie nie wymaga specjalnego wysiłku intelektualnego od odbiorcy (Levinson, 2010). Odbiorca nie podejmuje próby upewnienia się, czy i na ile presupozycje przekazywane w komunikatach są prawdziwe. Presupozycje stanowią więc istotne narzędzie wpływu na odbiorcę za pomocą języka (manipulacja językowa). 


\section{RODZAJE PRESUPOZYCJI}

Presupozycjaumożliwiawypowiedzeniezdania, którezawierainny sądniżtenznajdujący się „na powierzchni”. Cojeszcze warto wiedziećo presupozycji? Przede wszystkim to, że istnieje kilka jej rodzajów. Znajomość różnych rodzajów presupozycji jest ważna dla pełnego zrozumieniai odczytania presupozycji pragmatycznych, zawartych w wypowiedziach sformułowanych przez nadawców.

Presupozycja czasowa wykorzystuje takie operatory jak: zanim, kiedy, w trakcie, po, przed, nadal, ciagle...

Przykład: W czasie spotkania wyjaśnię ci pojęcie presupozycji.

Presupozycją w powyższym przykładzie jest fakt, iż odbiorca zdania nie rozumie pojęcia presupozycji - trzeba mu je przybliżyć, aby zrozumiał definicję. Drugą presupozycją wynikającą ze zdania jest fakt, że odbędzie się spotkanie nadawcy komunikatu i jego odbiorcy (Kolarzowski, 2006).

Presupozycja świadomościowa związana jest z rozumieniem. Wykorzystuje takie operatory jak: zdawać sobie sprawę, mieć świadomość, wiedzieć, zauważyć, dostrzegać...

Przykład: Piotr miał świadomość, że jadąc samochodem, potracił sarnę.

W tym przykładzie presupozycją jest fakt, iż sarna wybiegła na ulicę i doszło do zderzenia zwierzęcia i samochodu. Drugą presupozycją jaką możemy założyć w odniesieniu do powyższego zdania jest fakt, iż Piotr posiada prawo jazdy.

Presupozycja porządkowa wykorzystuje takie operatory jak: następny, kolejny, drugi, trzecie, nieustannie, znowu...

Przykład: Anna kolejny raz nie zdała egzaminu.

W powyższym zdaniu presupozycją jest informacja, że Anna już kilka razy przystępowała do zdania egzaminu i za każdym razem wynik był negatywny.

Presupozycja wyboru związana jest z możliwością wyboru i wykorzystuje takie operatory jak: lub, albo, chyba że, czy ...

Przykład: Adam wybierze z karty dań rybę lub wołowinę.

Pierwszą presupozycją jaką możemy wywnioskować na powyższym przykładzie jest informacja, że Adam przebywa w restauracji, jest głodny i chce zamówić jedzenie. Drugą presupozycję stanowi fakt, że Adam ma wybór między przynajmniej dwoma daniami. Możemy jeszcze założyć trzecią presupozycję - mianowicie, iż Adam nie jest wegetarianinem i nie przebywa w wegetariańskiej restauracji.

Presupozycja przymiotnikowa lub przysłówkowa w swojej konstrukcji wykorzystuje takie operatory jak: ciekawie, przyjemnie, doskonale, radośnie, szybko.

Przykład: Jacek nauczył się pływać doskonale.

Presupozycję w powyższym przykładzie stanowi fakt, że Jacek nie umiał pływać lub umiał pływać jednie amatorsko. Drugą presupozycja, która wynika z tego zdania, jest komunikat, że Jacek podjął naukę pływania z pozytywnym efektem. 


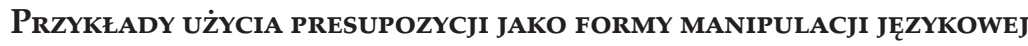

\section{Przykład I}

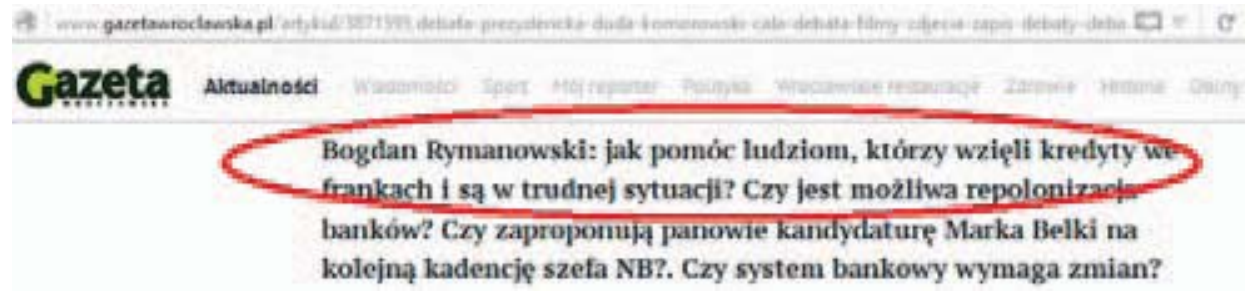

Bogdan Rymanowski jest dziennikarzem stacji TVN. Razem z Moniką Olejnik i Justyną Pochanke 21 maja 2015 roku poprowadził drugą debatę prezydencką przed II turą wyborów prezydenckich. Debata transmitowana była przez TVN, TVN24, TVN24 Biznes i Świat. Pierwsza debata odbyła się 17 maja 2015 r.

Presupozycja, którą zawiera pytanie Bogdana Rymanowksiego może być przykładem manipulacji. Dziennikarz bowiem nie pyta, czy w ogóle potrzebna jest pomoc dla ludzi, którzy wzięli kredyty we frankach, czy kandydaci na prezydenta biorą pod uwage pomoc kredytobiorcom, ale od razu sugeruje, iż taka pomoc jest potrzebna. Taka manipulacja skierowana jest przede wszystkim w kierunku kandydatów na prezydenta, ale również i widzów, którzy oglądają debatę. W świadomości odbiorców rodzi się wniosek, że ludzie, którzy wzięli kredyty we frankach potrzebują wsparcia ze strony państwa. Odbiorca takiego komunikatu już nie będzie zastanawiał się, czy taka pomoc jest im potrzebna, ale zacznie rozważać, w jaki sposób państwo może wspomóc tzw. „,frankowiczów”. Pytanie o zasadność pomocy zostanie sprowadzone na dalszy plan.

Drugą informacją którą presuponuje Bogdan Rymanowski, jest powiązanie wzięcia kredytu we frankach i znalezienie się w trudnej sytuacji. Dziennikarz przemyca więc kolejny sąd - osoby, które wzięły kredyt we frankach znajdują się w trudnej sytuacji. Co oczywiście nie zawsze jest prawdą, ponieważ istnieją osoby, które mimo, że wzięły kredyt we frankach, którego kurs poszedł w górę, nie znalazły się w trudnym położeniu. Jednak dzięki tak przedstawionemu komunikatowi, w świadomości odbiorców pojawia się wniosek, że osoby posiadające kredyt we frankach mają niełatwą sytuację. Informacje przemycane w taki sposób mogą przyczynić się do tego, że w razie wsparcia "frankowiczów" pieniędzmi z budżetu państwa sprzeciw społeczny będzie z pewnością mniejszy.

\section{Przykład II}

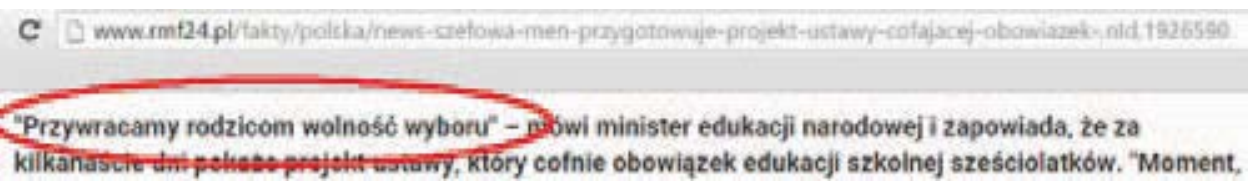


Cytowane powyżej zdanie zostało wypowiedziane przez Annę Zalewska, która była Ministrem Edukacji Narodowej w rządzie Beaty Szydło. Cytat ten odnosi się do wprowadzenia obowiązku pójścia sześciolatków do szkoły, który wprowadziła Platforma Obywatelska. Zrobiła to bez żadnej konsultacji ze społeczeństwem, przez co wokół ustawy powstało wiele kontrowersji. Obowiązek pójścia sześciolatków do szkoły wzbudził protesty zarówno rodziców, jak i nauczycieli. Wielu rodziców omijało ten obowiązek poprzez zdobycie zaświadczenia dla swoich dzieci o niedojrzałości szkolnej u dziecka.

Logiczną konsekwencją powyższej wypowiedzi: „przywracamy rodzicom wolność wyboru", jest fakt, że wolność ta została im odebrana. Jest to przekazanie informacji rodzicom, uświadomienie faktu, że sami nie mogą decydować o edukacji własnych dzieci. Drugą presupozycją jaka wynika z tej odpowiedzi, jest informacja "przywracamy", czyli PiS jest tą sprawiedliwą partia, która oddaje to, co obywatelom zostało zabrane.

Obydwie presupozycje, które zostały umieszczone w tym krótkim zdaniu, mogą w znaczący sposób oddziaływać na odbiorców. Przede wszystkim dzięki tej technice rodzice zdają sobie sprawę, ze zostało im odebrane coś, do czego mają prawo - czyli decydowanie o edukacji szkolnej własnych dzieci. Z pewnością taka świadomość może wzbudzić frustrację i złość na kogoś, kto zabrał im możliwość decydowania o tym, czy ich dziecko pójdzie do szkoły w wieku lat sześciu czy siedmiu. Kolejnym wnioskiem, jaki może zrodzić się w świadomości odbiorców z tejże wypowiedzi, staje się myśl, że skoro partia rządząca zabiera możliwość wyboru, to nie jest partią dobrą i proobywatelską. Taka presupozycja ma więc za zadanie przedstawić negatywny wizerunek Platformy Obywatelskiej. Jeszcze innym wnioskiem, jaki może zrodzić się w głowie odbiorcy po usłyszeniu takiej wypowiedzi, jest myśl, że to Prawo i Sprawiedliwość jest tą partia, która troszczy się o prawa obywateli, troszczy się o to, by rodzice mogli sami zadecydować o tym, kiedy ich dziecko pójdzie do szkoły. Inną reakcja, jaką może wywołać tak zastosowana presupozycja, jest wdzięczność obywateli. Skoro ktoś przywraca im to, co zostało wcześniej odebrane, może być przyczyną wywołania takich właśnie odczuć. Taka presupozycja ma również na celu kreowanie dobrego, przyjaznego i troskliwego wizerunku partii rządzącej.

\section{Przykład III}

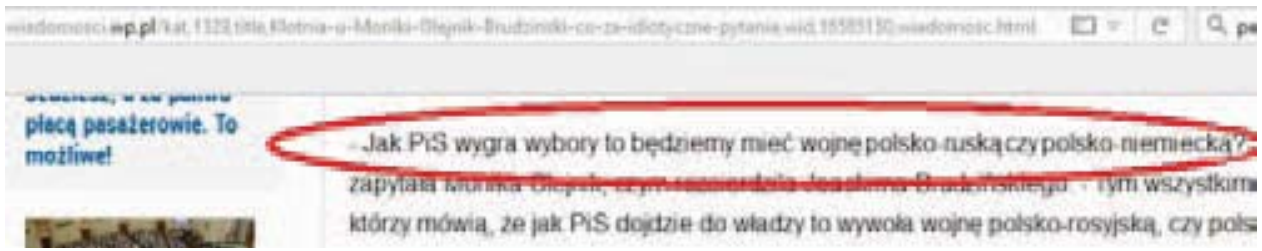

Gościem Moniki Olejnik prowadzącej w Radiu Zet wywiady z politykami był Joachim Brudziński. Jest on politykiem przynależącym do Prawa i Sprawiedliwości. Monika Olejnik zadała gościowi pytanie, które dotyczyło jego partii, a dokładniej jej ewentualnej wygranej. 
Logiczną konsekwencją pytania Moniki Olejnik jest to, że jeśli PiS dojdzie do władzy, nastanie czas niepokoju i konfliktów. Dziennikarka stawia alternatywę, czy będzie to wojna polsko-niemiecka, czy polsko-rosyjska. Jednak to nie jest istotne. Kluczowe znaczenie ma komunikat, że PiS będzie prowadził politykę agresywną i zaczepną. Pytanie zadane w ten sposób - z ukrytą presupozycja, może oddziaływać na obraz partii w świadomości obywateli.

Konsekwencją tak zastosowanej presupozycji może być negatywny obraz Prawa i Sprawiedliwości w opinii publicznej. Taka presupozycja może zrodzić obraz PiSu, jako partii agresywnej, która chce wywołać wojnę. Tego rodzaju zabieg jest formą przedstawienia odbiorcom wizji przyszłości, że jeśli wybiorą tę partię, to Polskę czekają konflikty. Jego zastosowanie przed wyborami parlamentarnymi 2015, mogło obniżyć poparcie dla Prawa i Sprawiedliwości.

\section{Podsumowanie}

We współczesnym dyskursie medialnym $\mathrm{w}$ wypowiedziach zarówno polityków, jak i dziennikarzy można dostrzec manipulacje językowe za pomocą użycia presupozycji. Tego rodzaju działania sa jednym ze sposobów wpływania na świadomość odbiorców i przemycania ukrytych intencji w nadawanym komunikacie.

Dzięki analizie jakościowej wybranych przykładów i przedstawieniu kontekstu powstania wypowiedzi, została ukazana pewna tendencja, której obserwacja nakreśla, w jaki sposób nadawcy komunikatów posługują się presupozycjami, by przemycić swoje sądy. Osoby stosujące tę formę pragmatyczną potrafią przemycić swój pogląd do świadomości odbiorcy. Brak bezpośredniej ingerencji ze strony nadawcy jest przyczyną utrwalania się takich sądów i opinii w rozumowaniu odbiorcy.

Dzięki presupozycjom manipulacje stają się zdecydowanie bardziej skuteczne, ponieważ nie trafiają wprost do świadomości adresatów. Nadawcy komunikatów potrafią umiejętnie manewrować przekazem, przez co odbiorcy łatwiej przyswajają treści i formułują sądy, które są zamiarem nadawcy.

\section{BibLIOGRAFIA:}

[1] Kolarzowski, J. (2006). Użycie presupozycji jako werbalnego środka wywierania wptywu. Pobrane z: http://www.racjonalista.pl/kk.php/s,4927.

[2] Levinson, S.C. (2010). Pragmatyka językowa. Warszawa: Wydawnictwo Naukowe PWN.

[3] Maciuszek, J. (2013). Automatyzmy i bezrefleksyjność w kontekście wptywu spotecznego. Warszawa: Wydawnictwo Naukowe PWN.

[4] Maciuszek, J., Garlicka. J. (2017). Refleksyjność jako czynnik odporności na zawarte w pytaniu presupozycje. Psychologia Społeczna, tom 121 (40).

[5] Rusesell, B. (1905). On Denoting [O denotowaniu]. Mind, 14 (56), 479-493.

[6] Strawson, P. F. (1950). On Referring [O wyrażaniu]. Mind, 59 (235), 320-344. 